\title{
Refurbishment of a Three-Phase Induction Motor Reflecting Local Voltage Condition
}

\author{
Enyong P.M ${ }^{1}$, Anyaeji C.A ${ }^{2}$ and Izuagie F.I ${ }^{3}$ \\ ${ }^{1,3}$ Department of Electrical and Electronic Engineering, Auchi Polytechnic, Auchi \\ ${ }^{2}$ Department of Electrical and Electronic Engineering, university of Benin Benin city
}

\begin{abstract}
A 2.2-kW, 3-phase, $50 \mathrm{~Hz}$ squirrel-cage induction motor originally designed for $415 \mathrm{~V}$ (a.c.) application got burnt out from sustained thermal overload. Being that the local supply voltage hardly rises above $380 \mathrm{~V}$ (a.c.), it had to be refurbished from first principles to reflect this voltage condition. The calculations leading to the choice of the number of poles, number of coils per phase per pole, number of phase groups, number of turns-in-series per phase, amongst other quantities, necessary for the realization of a $380 \mathrm{~V}$ (a.c.) double-layer lap-type 3-phase stator winding with a diamond overhang were carried out. The method of directon-line starting was used to check the workshop performance of the machine. The value of the motor no-load speed was quite satisfactory. It is, however, emphatically recommended that a suitable under-voltage relayprotection scheme be incorporated in the motor power supply system to forestall such breakdown in future.
\end{abstract}

Keywords: Induction Motor, Refurbishment, Local Voltage Condition.

\section{Introduction}

The induction motor as an electromechanical rotating equipment has been of great significance to industrialists since it came into existence in 1833[Say \& Taylor, 1980]. For instance, the motor in question was used to drive a grinding tool in an electrical workshop. But having been left to run under a low voltage supply condition overnight, it became seriously overheated and got burnt as a result. In refurbishing the motor, it was considered necessary to adopt winding parameters relative to $380 \mathrm{~V}$ (a.c.) which was the maximum local supply voltage level; whereas, the motor name-plate voltage specification was $415 \mathrm{~V}$ (a.c.). Therefore, in Section 3.0 the machine calculations to that effect are presented, being preceded by the motor measurement details in Section 2.0. Section 4.0 deals with the refurbishment work proper. Section 5.0 provides details of the machine test results; whilst, conclusion and recommendations constitute the terminal part of this paper in Section 6.0.

\section{Motor Measurement Details}

First principle approach to cage motor stator refurbishment often involves measurement of the stator axial length and bore diameter, together with the slot, tooth and core dimensions. Essential measurements are also normally taken on the rotor. Of course, these measurements usually precede the actual machine calculations and the details are given below in Table 2.1.

Table 2.1: Values obtained from Essential Measurements of the Motor Stator and Rotor.

\begin{tabular}{|l|l|l|l|}
\hline \multicolumn{1}{|c|}{ ITEM } & VALUE & ITEM & VALUE \\
\hline i) Stator Bore Diameter (D) & $92 \mathrm{~mm}$ & v) Rotor Bar Spacing (or slot pitch) & \\
ii) Effective Axial Length (L) & $98 \mathrm{~mm}$ & vi) Skew of Bars & $9.5 \mathrm{~mm}$ \\
iii) Number of Stator Slots (S) & 36 & vii) Effective Rotor Axial & $9.5 \mathrm{~mm}$ \\
iv) Number of Rotor Bars & 32 & Length & $98 \mathrm{~mm}$ \\
\hline
\end{tabular}

N.B: (i) Source: Form direct measurement and inspection of the motor.

(ii) Other Dimensions are as shown in Fig. 2.1 below

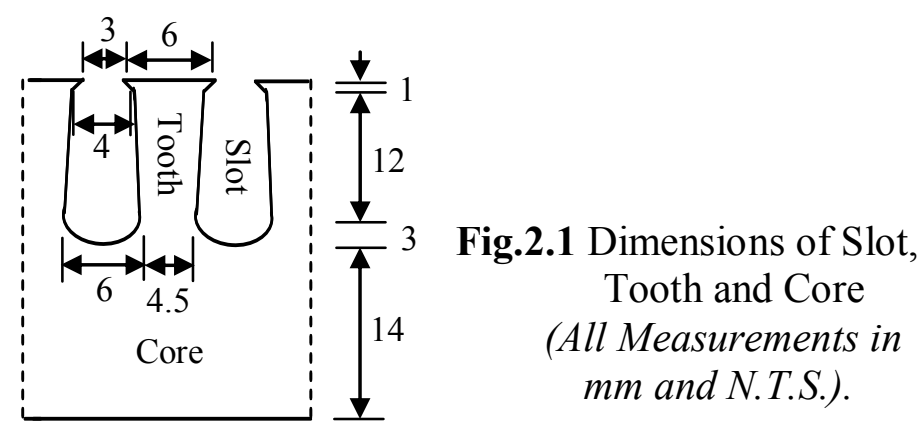


3.1Choice of No. of Poles (2p):

\section{Machine Calculations}

The synchronous speed, $\mathrm{N}_{\mathrm{s},}$ of a motor is given by

$$
N_{s}=120 f / 2 p=N_{r} /(1-s)
$$

Where $\mathrm{p}$ - pole pairs; $\mathrm{N}_{\mathrm{r}}-$ rotor speed; $\mathrm{s}=$ slip. Thus, with $\mathrm{N}_{\mathrm{r}}=1420 \mathrm{rpm}$ (from name-plate), and applying a slip of $5 \%$ which is the standard value for most practical machines according to [Say, 1976], we obtain the synchronous speed from (3.1) as

$$
N_{s}=1420 /(1-0.05)=1495 \mathrm{rpm}
$$

or the preferred value of $\underline{1500 \mathrm{rpm}}$ as in [Say, 1983]. Hence, the number of poles becomes

3.2 Slot Pitch ( $\lambda)$ :

$$
2 p=\frac{120 f}{N_{s}}=\frac{120 \times 50}{1500}=4(\text { exactly }) \text {. }
$$

For stator slots, $\mathrm{S}=36$ we shall have, in terms of angle, the slot pitch given by

$$
\lambda=\frac{180(2 p)}{S}=\frac{180 \times 4}{36}=20^{\circ} \text { elect }
$$

3.3 No. of Coils (or Slots) per Pole per Phase (q):

The number of coils (or slots) per pole per phase is given by

$$
q=S / 2 p m=36 /(4 \times 3)=3
$$

This is OK since 'q' should be at least 3 to avoid excessive reactance [Say, 1983].

\subsection{Pole Pitch $(\tau)$ :}

In electrical degrees, we have

$$
\left.\tau={ }_{180}{ }^{\circ} \text { (i.e. } \pi \text { rad. }\right) \text { elect } .=(180 / 20) \lambda=9 \lambda
$$

3.5 Coil Pitch $(\gamma)$ /Relative Chording Factor ( $\beta$ ):

Machine coil pitches in practice usually fall between ( $2 / 3) \tau$ and $\tau$ [Say, 1976]; implying that relative chording factors will fall between $2 / 3$ and 1 , exclusively. Hence, for a pole pitch, $\tau=9 \lambda$, the coil pitch should be either (7/9) $\tau$ or $(8 / 9) \tau$ (meaning a relative chording factor of either $(7 / 9)$ or $(8 / 9)$. We shall select (8/9) for the motor, since chording equally reduces phase e.m.f.'s. Therefore, the motor coil pitch shall be

$$
\gamma=\beta \tau=(8 / 9) \tau=8 \lambda=160^{\circ} \text { elect }
$$

Fortunately, the skewed cage rotor slots shall also help to suppress those high-order harmonics whose influence cannot be suppressed by the choice of relative chording factor, $\beta$ [Liwschitz-Garik \& Whipple].

3.6 Pitch Factor $\left(K_{\mathrm{pn}}\right)$ :

Generally, the coil pitch factor for the nth harmonic is given by

$$
K_{p n}=\sin \frac{n \beta \pi}{2}=\sin \frac{n \gamma}{2} \quad \text { [Chalmers, 1965] }
$$

Thus, fundamentally we have

$$
K_{p 1}=\sin \frac{(8 / 9) \pi}{2}=0.985
$$

\subsection{Phase-Spread Angle ( $\sigma) /$ Winding Layer Method:}

For a high-order distribution factor, the spread angle $\sigma=60^{\circ}$ (elect.) shall be chosen. A double-layer winding design has a lower leakage reactance and produces a better phase e.m.f. waveform than the corresponding single-layer winding design [Daniels, 1976]. Thus, a double-layer (i.e. "basket") winding method shall be adopted.

3.8 No. of Phase-group Coils $(\Theta)$ :

This is given by

$$
\begin{aligned}
\Theta & =p(2 \pi) / \sigma=360 p / \sigma \\
& =2 \times 360 / 60=12
\end{aligned}
$$

\subsection{Distribution Factor $\left(\mathbf{K}_{\mathrm{dn}}\right)$ :}

Usually, for an integral-slot winding (such as the design in question), the distribution factor is calculated from the equation involving harmonics given as 


$$
K_{d n}=\frac{\sin 0.5(n \sigma)}{q \sin 0.5(n \sigma / q)} \quad[\text { Say, 1976] }
$$

Hence, the fundamental distribution factor is,

$$
K_{d 1}=\frac{\sin 0.5(1 \times 60)}{3 \sin 0.5(1 \times 60 / 3)}=0.96
$$

3.10 Winding Factor $\left(K_{w n}\right)$ :

$$
K_{w n}=K_{d n} . K_{p n}
$$

Thus, for an integral-slot winding design, the fundamental winding factor is

$$
K_{w l}=K_{d l} . K_{p l}=0.96 \times 0.985=0.946
$$

3.11 Specific Magnetic Loading $\left(B_{\text {av. }}\right)$ :

The stability and dynamic conditions of induction machines are highly affected by saturation [Okoro, 2003]. Thus, the choice of $\mathbf{B}_{\mathbf{a v}}$ is usually between 3 and 6Tesla [Singh, 1982]. We shall assume $\mathbf{B}_{\mathbf{a v}}=\mathbf{0 . 4 9 T e s l a}$.

3.12 Flux per Pole $\left(\Phi_{\mathbf{p}}\right)$ :

$$
\begin{aligned}
\Phi_{p} & =(\pi D L / 2 p) B_{a v} \\
& =(\pi \times 0.092 \times 0.098 / 2 \times 2) \times 0.49=0.00347 \mathrm{~Wb}
\end{aligned}
$$

3.14 Total No. of Turns (N), Total No. of Conductors $(Z)$

\& No. of Conductors per Slot $\left(Z^{\prime}\right)$ :

$$
N=3 N_{p h} ; Z=2 N ; N_{p h}=\frac{E_{p h}}{4 \Phi_{p} f_{b} f K_{w 1}}
$$

where $f_{b}=1.11$ and $f=50 \mathrm{~Hz}$; [Kuale, 2003].

$$
\begin{aligned}
& N_{p h}=\frac{380}{4 x 0.00347 \times 1.11 \times 50 \times 0.946}=521 ; \quad N=3 \times 521=1563 ; \\
& Z=2 \times 1563=3126 ; \text { therefore, } \quad Z^{\prime}=3120 / 36=86.83
\end{aligned}
$$

Since the value of $Z^{\prime}$ must be exactly divisible by 2 to give layers of equal number of conductors, we shall take $Z^{\prime}$ $=88$. Consequently, we have

$$
Z=88 \times 36=3168 \text { and } N_{p h}=3168 / 2 \times 3=528
$$

3.15 No. of Conductors per Layer $\left(Z^{\prime \prime}\right) /$ No. of Turns per Coil $\left(N_{c}\right)$ :

$$
Z^{\prime \prime}=Z^{\prime} / 2=N_{c}=88 / 2=44
$$

3.16 Size of Conductor (S. W. G.):

By inspection of Fig.2.1 the approximate area of slot (or gross area), $\mathrm{A}_{\mathrm{sg}}$, is

$$
A_{s g}=\frac{1 x(3+4.8)}{2}+\frac{12(4.8+6.5)}{2}+\frac{\pi_{3}{ }^{2}}{2}=86 \mathrm{~mm}^{2}
$$

where

$$
=A_{c} / S F=Z^{\prime} \cdot a_{c} / S F
$$

$\mathrm{A}_{\mathrm{c}}-$ Cross-sectional area of Total Conductors per Slot.

$a_{c}=\pi\left(d_{c}{ }^{2}\right) / 4$, cross-sectional area of each conductor.

$\mathrm{SF}-$ Space Factor $\{0.25$ to 0.4$\}$ [Agarwal, 2000].

Thus, applying $\mathrm{SF}=0.25$, we have conductor diameter as

$$
d_{c}=(4 \times 0.25 \times 86 / 88 \pi)^{1 / 2}=0.5577 \text { or } 0.56 \mathrm{~mm} ;
$$

Whereby we select copper wire of S.W.G. 24 as in standard workshop S.W.G. Tables.

\subsection{No. of Wires in Hand:}

Obviously, one (1) wire in hand of 44-conductor coil per layer is OK

3.18 Winding Formation:

The lap winding formation is the most common in practice and shall be used here.

3.19 Slot Allocation to Phase-Group Coil Sides as Designed.

Table 3.1 Slot Allocation to Phase-Group Coil Sides.

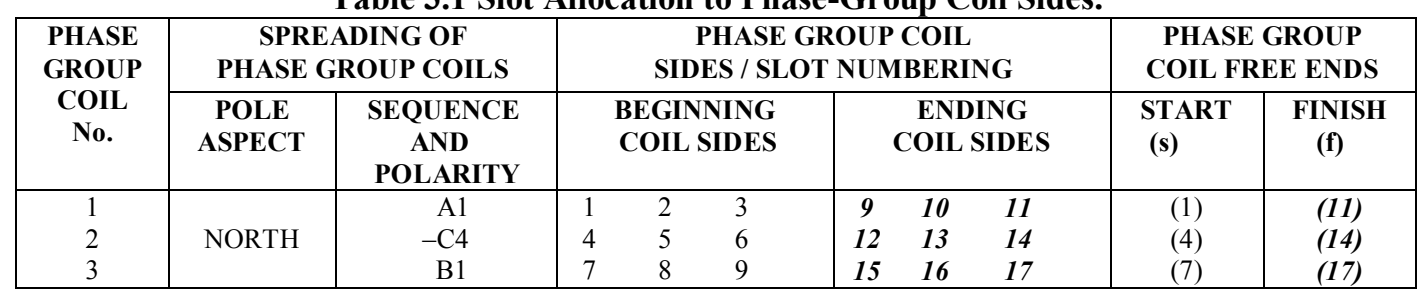




\begin{tabular}{|c|c|c|c|c|c|c|c|c|c|c|}
\hline $\begin{array}{l}4 \\
5 \\
6 \\
\end{array}$ & SOUTH & $\begin{array}{r}-\mathrm{A} 2 \\
\mathrm{C} 1 \\
-\mathrm{B} 2\end{array}$ & $\begin{array}{l}10 \\
13 \\
16\end{array}$ & $\begin{array}{l}11 \\
14 \\
17\end{array}$ & $\begin{array}{l}12 \\
15 \\
18\end{array}$ & $\begin{array}{l}18 \\
21 \\
24\end{array}$ & $\begin{array}{l}19 \\
22 \\
25\end{array}$ & $\begin{array}{l}20 \\
23 \\
26\end{array}$ & $\begin{array}{l}(10) \\
(13) \\
(16)\end{array}$ & $\begin{array}{l}(20) \\
(23) \\
(26)\end{array}$ \\
\hline 7 & & A3 & 19 & 20 & 21 & 27 & 28 & 29 & (19) & (29) \\
\hline 8 & NORTH & $-\mathrm{C} 2$ & 22 & 23 & 24 & 30 & 31 & 32 & (22) & (32) \\
\hline 9 & & B3 & 25 & 26 & 27 & 33 & 34 & 35 & (25) & (35) \\
\hline 10 & & $-\mathrm{A} 4$ & 28 & 29 & 30 & 36 & 1 & 2 & (28) & (2) \\
\hline 11 & SOUTH & $\mathrm{C} 3$ & 31 & 32 & 33 & 3 & 4 & 5 & (31) & (5) \\
\hline 12 & & $-B 4$ & 34 & 35 & 36 & 6 & 7 & 8 & (34) & (8) \\
\hline
\end{tabular}

N.B.: (i) Ending/Lower Layer Coil Sides and 'Finish' Coil Sides are Italicized and emboldened; (ii) the sign (-) indicates negative polarity (elect.); (iii) Source: Allocation based on the foregoing design data.

\subsection{The Schematic Winding Diagram:}

The schematic winding diagram is as shown in Fig.3.1.

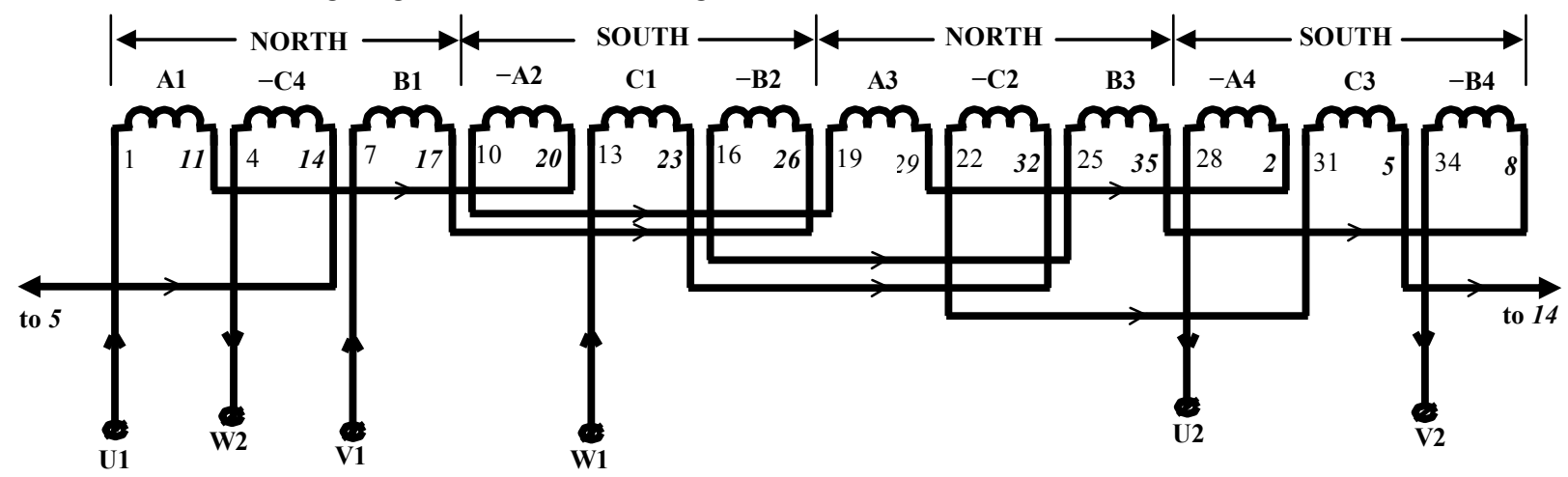

Fig.3.1: Schematic Winding Diagram Showing the 12 Phase-group Coils and their Arrangement under the 4 Poles and their Connection Pattern (i.e. Series/Series Connection).

\subsection{Rewinding of Stator}

\section{Refurbishment Work Proper}

\subsubsection{Preparation of Slots:}

A strip of slot liner or latheroid was used to cover the entire inner surfaces of the slots and made to shoot out of the slot up to $10 \mathrm{~mm}$ at least [Atabekov, 1980].

\subsubsection{Coil Production:}

A simple winding former was prepared with a plywood board and used to produce the required $72 \times 186 \mathrm{~mm}$ phase-belt coils of 44 turns per coil, leaving the free-end wire lengths up to $250 \mathrm{~mm}$. Next, each phase coil in a given phase group was duly separated with masking tape wrappings. A total of 12 phase groups were produced as per design.

\subsubsection{Coil Insertion into Slots \& Arrangement:}

As the machine stator is the open-slot type, each of the 12 phase group coils was carried into the slot area making sure that the free-end wires were on the connection side of the machine. The winding layout of Table 3.1 was skillfully followed in putting the coils into the slots and having them properly arranged. Thereafter, a slot wedge made of dry bambow wood was used to secure the coils in each slot. The overhang portions of the phase-group coils were adequately insulated from each other with glass-fibre cloth-tape.

\subsubsection{Coil Lead Connections/Pre-Impregnation Tests:}

a) Coil Lead Connections:

The twelve (12) phase-group coils gave rise to 24 No. coil leads. The 4 phase-group coils of phase A (i.e. A1, A2, A3 and-A4) were connected in series opposite formation to constitute one single circuit as in Fig.4.1 


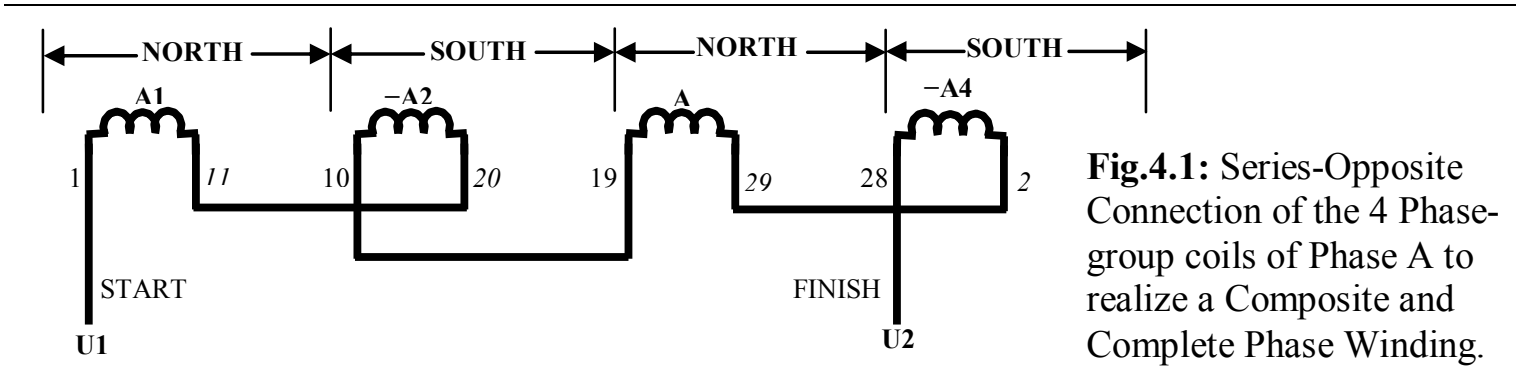

Phases $\mathrm{B}$ and $\mathrm{C}$ were each connected in the same manner forming altogether 3 composite phase windings with 6 terminal leads, (the "start" leads being 1or (U1), 7 or (V1) and 13 or (W1); the "finish" leads being 28 or (U2), 34 or (V2) and 4 or (W2), as shown in Fig.3.1.

b) Pre-Impregnation Workshop Tests:

Insulation resistance test was carried out and 5.4M $\Omega$ was got as the least value for phase-to-earth; $75 \mathrm{M} \Omega$ (least value) for phase-to-phase measurements. This was $\mathrm{OK}$ for a 1-minute test with $500 \mathrm{~V}$ (d.c.) @ $30^{\circ} \mathrm{C}$ in each case. Correctness of connections was then tested by energizing the winding (in star connection) with 110V(a.c.) 3phase (i.e. about $30 \%$ of the design voltage) and having a small iron ball placed inside the stator to serve as rotor. The iron ball was seen to roll round the stator bore as expected.

\subsubsection{Impregnation and Drying of Winding:}

Prior to impregnation, the stator winding was first dried in an oven at a temperature of $110^{\circ} \mathrm{C}$ for 2 hours according to [Atabekov, 1980]. Thereafter, the winding was impregnated with SECO Sterling (Air-dry type High Resistant) varnish while still hot for easy penetration. It was then dried again at the same temperature (i.e. $110^{\circ} \mathrm{C}$ ) for 3 hours (i.e. warm-up stage) and finally at $130^{\circ} \mathrm{C}$ (being of Class B insulation) for 6 hours only as in [Atabekov, 1980], being the baking stage of drying.

\subsection{Machine Assembly Processes in Brief}

Before joining the rotor to the stator the bearings were checked and confirmed OK and cup grease was packed into the bearings. Then, before the final tightening of nuts to secure the end-shields to the machine frame, care was exercised to ascertain that the rotor rotated freely within the stator and that there was no unusual bearing-end sound.

\section{Workshop Testing Of Motor}

5.1 Pre-Commissioning Tests/Checks:

The results obtained were as presented in Table 5.1.

Table 5.1 Results of Pre-Commissioning Tests/Checks

\begin{tabular}{|c|c|c|c|c|}
\hline $\mathbf{S} / \mathbf{N}$ & ACTION & RESULT & STANDARD & REMARK \\
\hline 1 & $\begin{array}{l}\text { Winding Insulation } \\
\text { Resistance Measurement } \\
\text { @ } 30^{\circ} \mathrm{C} \text { for } 1 \text { minute, with } \\
\text { test voltage of } 500 \mathrm{~V} \text { (d.c.). }\end{array}$ & $\begin{array}{l}\text { i)Phase-to-Phase: } \\
\mathrm{U} 1-\mathrm{V} 1=75 \mathrm{M} \Omega \\
\mathrm{V} 1-\mathrm{W} 1=93 \mathrm{M} \Omega \\
\mathrm{W} 1-\mathrm{U} 1=77 \mathrm{M} \Omega \\
\text { ii)Phase-to-Frame: } \\
\mathrm{U} 1-\text { Frame }=142 \mathrm{M} \Omega \\
\mathrm{V} 1-\text { Frame }=155 \mathrm{M} \Omega \\
\mathrm{W} 1-\text { Frame }=146 \mathrm{M} \Omega\end{array}$ & $\begin{array}{l}1 \text { min. value @ } 40^{\circ} \mathrm{C} \text { not } \\
\text { less than }(\mathrm{kV}+1) \mathrm{M} \Omega \\
\quad \text { or } \\
\text { not less than } 1.96(\mathrm{kV}+1) \\
\mathrm{M} \Omega @ 30^{\circ} \mathrm{C} \text { [Enyong, } \\
2004] .\end{array}$ & $\begin{array}{l}\text { Megohmmeter used: } \\
\text { Digital, } \\
\text { BM 221, AVO INT. Ltd., } \\
\text { England. } \\
\text { All Readings } \\
\quad \text { OK. }\end{array}$ \\
\hline \multirow[t]{2}{*}{2} & Continuity Check & $\begin{array}{l}\mathrm{U} 1-\mathrm{U} 2=0.00 \Omega \\
\mathrm{V} 1-\mathrm{V} 2=0.00 \Omega \\
\mathrm{W} 1-\mathrm{W} 2=0.00 \Omega\end{array}$ & $\begin{array}{l}\text { Continuous } \\
\text { Circuit. }\end{array}$ & \multirow[t]{2}{*}{$\begin{array}{l}\text { Multimeter used: ROBIN, } \\
\text { Model OM 500T Taut } \\
\text { Band Analog } \\
\text { Multimeter. }\end{array}$} \\
\hline & & $\begin{array}{l}\mathrm{U} 1-\mathrm{V} 1 \& \mathrm{~V} 2=\infty \\
\mathrm{U} 1-\mathrm{W} 1 \& \mathrm{~W} 2=\infty\end{array}$ & Open-circuit. & \\
\hline
\end{tabular}

5.2 Test-Running (or Commissioning)/Checks:

Shown below in Table 5.2 are the results as realized. 
Table 5.2: Test-Running Check Results

\begin{tabular}{|c|c|c|c|}
\hline $\mathbf{S} / \mathbf{N}$ & ACTION & RESULTS OBSERVED & REMARKS \\
\hline \multirow[t]{3}{*}{ 1) } & \multirow{3}{*}{$\begin{array}{l}\text { 330(a.c.) applied through } \\
\text { ammeters to machine } \\
\text { without load. This was the } \\
\text { supply voltage level at the } \\
\text { time. }\end{array}$} & $\begin{array}{l}\text { i) Starting Current: } \\
7.0 \mathrm{Amps}\end{array}$ & $\begin{array}{l}\text { Direct-on-Line Starting } \\
\text { Current. }\end{array}$ \\
\hline & & $\begin{array}{l}\text { ii) Running Current: } \\
1.2 \mathrm{Amps}\end{array}$ & No-Load current \\
\hline & & $\begin{array}{l}\text { iii) Running Speed: } \\
\text { 1500rpm }\end{array}$ & $\begin{array}{l}\text { No-Load Asynchronous } \\
\text { Speed. }\end{array}$ \\
\hline \multirow[t]{4}{*}{ 2) } & \multirow[t]{4}{*}{$\begin{array}{l}\text { Watching out for unusual } \\
\text { sound or vibration }\end{array}$} & i) No rubbing sound & $\begin{array}{l}\text { a) Rotor Clear from Stator. } \\
\text { b) Cooling fan/guard well } \\
\text { coupled. }\end{array}$ \\
\hline & & ii) No croaking sound & Bearing condition $\mathrm{OK}$ \\
\hline & & iii) No vibration & $\begin{array}{l}\text { Air-gap reluctance } \\
\text { relatively even (i.e. } \\
\text { machine alignment } \mathrm{OK} \text { ) }\end{array}$ \\
\hline & & iv) No humming sound. & $\begin{array}{l}\text { a) Absence of single-phasing } \\
\text { due to internal or external } \\
\text { open-circuit. } \\
\text { b) Voltage per turn OK }\end{array}$ \\
\hline \multirow[t]{2}{*}{ 3) } & \multirow[t]{2}{*}{$\begin{array}{l}\text { Checking for signs of } \\
\text { overheating or burning }\end{array}$} & i) No over-heating & $\begin{array}{l}\text { a) Absence of inter-turn } \\
\text { short-circuits. } \\
\text { b) Voltage per turn OK } \\
\text { c) Conductor S.W.G. OK }\end{array}$ \\
\hline & & $\begin{array}{l}\text { ii) No unusual odour; no } \\
\text { smoke }\end{array}$ & $\begin{array}{l}\text { Absence of insulation } \\
\text { failure from overheating }\end{array}$ \\
\hline
\end{tabular}

Source: From actual Workshop Test-Running Checks on the Motor.

\section{Conclusion:}

It can be seen from the test-running exercise that the supply voltage level was $330 \mathrm{~V}$ (a.c.). Even at this $86.84 \%$ of the design voltage, the refurbished motor produced a no-load speed of $1500 \mathrm{rpm}$ equal to the synchronous speed. Thus, there is no doubt that with the application of the full design voltage of $380 \mathrm{~V}$ (a.c.) the full-load speed shall be up to the name-plate stipulated value of $1420 \mathrm{rpm}$, if not more than that.

The following recommendations have become necessary, namely:

(i) A suitable under-voltage relay-protection scheme be should be incorporated in the motor supply system to save the machine from such a breakdown in future.

(ii) Care shall be required to use this motor, henceforth, only up to about $75 \%$ of full-load bearing in mind that the same old rotor circuits (magnetic and electrical) are still in place.

\section{References}

[1]. Agarwal R. K. (2000): Principles of Electrical Machine Design, $4^{\text {th }}$ Ed., S. K.Kataria \& Sons, Delhi.

[2]. Atabekov V. B. (1980): Transformer and Electrical Machine Maintenance and Repairs, Mir Publishers, Moscow.

[3]. Chalmers B. J. (1965): Electromagnetic Problems of Alternating Current Machines, vol.2, Mir Publishers, Moscow.

[4]. Daniels A. R. (1976): Introduction to Electrical Machines, $1^{\text {st }}$ Ed., Macmillan Press Ltd., London.

[5]. Enyong P. M. (2004): Design of A Star-Delta Starter Panel Suitable for 30kW(40Hp) Machine Applications with A Reverse Rotation Feature; Technology Education

[6]. Journal, A Journal of The School of Technical Education, Federal College of Education(Technical), Vol.5 No.1, pp175-188, Akoka - Lagos.

[7]. Kuale P. A. (2003): Electrical Machine Design Lecture Notes, Dept. of Elect./Elect. Dept., University of Benin, Benin-City, Nigeria.

[8]. Liwschitz-Garik M. and Whipple C. C. ( 19-- ): Alternating Current Machines, $2^{\text {nd }}$ Ed., D. Van Nostrand Co. Inc., Princeton, New Jersey.

[9]. Okoro O. I. (2003): MATLAB Simulation of Induction Machine with Saturable Leakage and Magnetizing Inductances, The Pacific Journal of Science and Technology, Vol.5 No.1, pp5-15, http://www.akamaiuniversity.us/PJST.htm

[10]. Say M. G. (1976): Alternating Current Machines, ELBS $4{ }^{\text {th }}$ Ed., Pitman Publishing Ltd., London.

[11]. Say M. G. and Taylor E. O. (1980): Direct Current Machines, $1^{\text {st }}$ Ed., Pitman Publishing Ltd., London.

[12]. Say M. G. (1983): Performance and Design of Alternating Current Machines, CBS Publishers \& Distributors, London.

[13]. Singh B. (1982): Electrical Machine Design, Vikas Publishing House PVT Ltd., New Delhi. 